\title{
The impact of cruise altitude on contrails and related radiative forcing
}

\author{
Christine Fichter ${ }^{1,3}$, Susanne Marquart ${ }^{2}$, Robert SAusen $^{* 1}$ and David S. LeE ${ }^{3}$ \\ ${ }^{1}$ Institut für Physik der Atmosphäre, DLR Oberpfaffenhofen, Weßling, Germany \\ ${ }^{2}$ Institut für Umweltphysik, Universität Heidelberg, Germany \\ ${ }^{3}$ Dalton Research Institute, Manchester Metropolitan University, Manchester, UK
}

(Manuscript received October 10, 2004; in revised form May 27, 2004; accepted June 3, 2005)

\begin{abstract}
Within the framework of the European Fifth Framework Project TRADEOFF, the impact of changing cruise altitudes on contrail coverage and corresponding radiative forcing was investigated. On the basis of the reference year 1992, a series of aircraft emissions inventories with changed flight altitudes was prepared. These emission scenarios provide flown distances, fuel consumption and $\mathrm{NO}_{x}$ emissions on a three-dimensional grid. The vertical resolution of these inventories was significantly increased over that used in former inventories. With a downshift of cruise altitude by $2000 \mathrm{ft}$ (Throughout this paper we denote flight levels in ft. 2000 $\mathrm{ft}$ convert to approximately $610 \mathrm{~m}$.), $4000 \mathrm{ft}$, and $6000 \mathrm{ft}$ global annual mean contrail coverage is reduced in an approximately linear manner, reaching a maximum decrease of almost $45 \%$ for a $6000 \mathrm{ft}$ lower cruise altitude. Contrary to this, a slight increase by $6 \%$ of global annual mean contrail coverage resulted for a 2000 $\mathrm{ft}$ higher maximum flight altitude. Relative changes of corresponding radiative forcing were shown to be very similar to those of contrail coverage. For changes in contrail coverage and radiative forcing associated with changes in flight altitudes, a strong seasonal and regional variability was found. This study only considers contrail radiative forcing. Trade-offs from other aviation related radiative impacts, e.g., from $\mathrm{CO}_{2}$ or $\mathrm{O}_{3}$, have not been studied.

\section{Zusammenfassung}

Im Rahmen des Projektes TRADEOFF wurde der Einfluss geänderter Flughöhen auf die Kondensstreifenbedeckung und den damit verbundenen Strahlungsantrieb untersucht. Für das Referenzjahr 1992 wurde eine Reihe von Luftverkehrsemissionskatastern mit geänderten Flughöhen entwickelt. Diese Emissionsszenarien stellen geflogene Distanzen, Treibstoffverbrauch und Stickoxidemissionen auf einem dreidimensionalen Gitter bereit. Gegenüber früheren Luftverkehrsemissionskatastern wurde die Vertikalauflösung beträchtlich erhöht. Die jahresgemittelte globale Kondensstreifenbedeckung nimmt ungefähr linear mit der Flughöhe ab, wenn letztere um $2000 \mathrm{Fuß}, 4000 \mathrm{Fu}$ und $6000 \mathrm{Fuß}$ reduziert wird, und erreicht eine maximale Abnahme von etwa $45 \%$ für $6000 \mathrm{Fuß}$ tiefere Flugniveaus. Im Gegensatz dazu führt eine Erhöhung der Flugniveaus um 2000 Fuß zu einer geringen Zunahme der jahresgemittelten Kondensstreifenbedeckung um $6 \%$. Die entsprechenden relativen Änderungen des Strahlungsantriebes sind denen der Kondensstreifenbedeckung sehr ähnlich. Für die Änderungen der Kondensstreifenbedeckung und des Strahlungsantriebes ergibt sich eine hohe saisonale und regionale Variabilität. In der vorliegenden Arbeit wird nur der Strahlungsantrieb aufgrund von Kondensstreifen betrachtet, andere Beiträge zum Strahlungsantrieb des Luftverkehrs z. B. aufgrund von $\mathrm{CO}_{2}$ oder $\mathrm{O}_{3}$ wurden nicht untersucht.
\end{abstract}

\section{Introduction}

Aviation has a number of impacts upon climate through direct and indirect effects that were evaluated by the Intergovernmental Panel on Climate Change (IPCC) in terms of radiative forcing of climate (PENNER et al., 1999). These include: direct emissions of carbon dioxide $\left(\mathrm{CO}_{2}\right)$, emissions of nitrogen oxides $\left(\mathrm{NO}_{x}\right)$ that affect both tropospheric and stratospheric ozone $\left(\mathrm{O}_{3}\right)$ and ambient levels of methane $\left(\mathrm{CH}_{4}\right)$, direct effects of water vapour, sulphate and soot particles, condensation trails

\footnotetext{
*Corresponding author: Robert Sausen, DLR-Institut für Physik der Atmosphäre, Oberpfaffenhofen, 82234 Weßling, Germany, e-mail: robert.sausen@dlr.de
}

(contrails) and potential enhancement of cirrus cloud coverage.

The impact of line-shaped contrail coverage on radiative forcing was recently evaluated by several groups (Myhre and Stordal, 2001; MEYer et al., 2002; MARQUART et al., 2003) to be smaller than was reported by the IPCC Report (PENNER et al., 1999). Nonetheless, the effect that contrail coverage has on radiative forcing may still be substantial, since persistent contrails can evolve into non-linear, cirrus-like clouds, which could cause a strong warming (PENNER et al., 1999; SAUSEN et al., 2005). Recent studies have provided evidence that aviation may increase cirrus cloud formation, particularly by the aging of contrails (ZEREFOS et al., 
2003; Minnis et al., 2004; MANNSTEIN and SCHUMANN, 2005; STORDAL et al., 2005). As an upper estimate, aircraft-induced cirrus clouds might cause a radiative forcing from the same magnitude as all other aircraft perturbations together (SAUSEN et al., 2005). Even though the confidence level for radiative forcing of aircraft-induced cirrus clouds is still poor and the range of modelled results is considerable, this indirect effect of contrails could be an important fraction of the total radiative forcing from aircraft. It is therefore useful to investigate potential strategies for the reduction of contrail coverage to prevent or at least reduce their direct and indirect effects on radiative forcing.

Actual cruise altitudes of aircraft mainly result from fuel and flight time efficiency with the constraints imposed by aircraft aerodynamics and air traffic management. Potential climate impacts are not considered in this process. As the climatic impact of air traffic is not only dependent on fuel consumption and the corresponding emission of $\mathrm{CO}_{2}$, there exists a potential to reduce the overall aircraft climate impact by changing maximum flight altitudes and reducing aircraft climate effects other than that from $\mathrm{CO}_{2}$. In particular, the coverage by persistent contrails might be reduced, as their formation is highly dependent on ambient atmospheric conditions, which vary with altitude. Other aircraft emissions like $\mathrm{NO}_{x}$ and the subsequent production of $\mathrm{O}_{3}$ also change for a change in flight altitudes (GREWE et al., 2002; GAUSS et al., 2004). In the present study, only effects on contrails and their radiative forcing were investigated.

According to the revised thermodynamic theory (e.g. SCHUMANN, 1996), the formation of contrails mainly depends upon ambient humidity, temperature, pressure, the emission index of water vapour and the overall propulsion efficiency of the aircraft. In addition, it is necessary that the atmosphere is supersaturated with respect to ice to allow for the persistence of a contrail. Figure 1 shows the potential coverage of persistent contrails for January and July mean conditions for the year 1992 as calculated with the General Circulation Model (GCM) ECHAM4.L39(DLR) (ROECKNER et al., 1996; LAND et al., 1999, 2002). The potential contrail coverage is the maximum contrail coverage that could be obtained for a given atmospheric state if aircraft were flying everywhere (details see SAUSEN et al., 1998). How the potential contrail coverage was calculated within the ECHAM model is explained in section 3 together with a brief description of the contrail parameterisation. Regions that are moist and cold enough to allow for the formation of persistent contrails mainly occur in the tropopause region. Figure 1 shows a strong seasonal cycle of potential contrail coverage particularly at middle and higher latitudes. The potential coverage with persistent contrails is not confined to the tropopause region
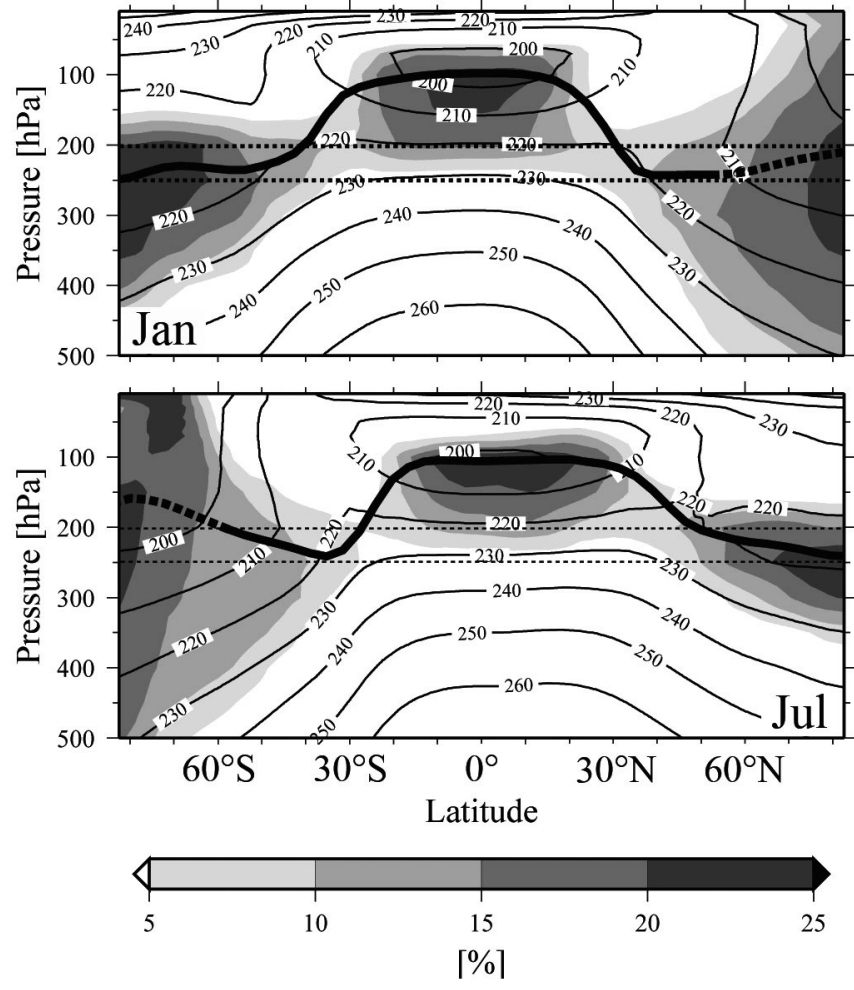

Figure 1: Zonal mean potential coverage with persistent contrails (shading in \%), for January (upper panel) and July (lower panel) mean conditions as calculated with the ECHAM4.L39(DLR) GCM from a five year integration for 1992 conditions. The bold line indicates the thermal tropopause, which is not well defined in the polar winter atmosphere (dotted). The main aircraft cruise altitudes are indicated by the finer dotted lines. The isolines display the zonal mean temperature $[\mathrm{K}]$.

in the respective winter hemispheres, which reflects the annual temperature and humidity variation in those regions. This indicates that contrail formation is possible much more frequently in winter than it is in summer. As aircraft cruise altitudes are mainly located between 200 and $250 \mathrm{hPa}$, a particularly large part of the air traffic flies in regions where contrails are very likely to form, especially in the extra-tropics. Thus, contrail coverage might be reduced by shifting cruise altitudes to higher or lower flight levels, with ambient conditions that are less likely to allow for the formation and persistence of contrails.

A simplified parametric study of the impact of cruise altitudes on contrail coverage was performed by SAUSEN et al. (1998). In SAUSEN et al.'s (1998) study, air traffic was artificially displaced up and down by $1 \mathrm{~km}$ relative to a base case. They considered neither aerodynamic constraints nor the impacts on fuel consumption. For the TRADEOFF aircraft emission scenarios, which were used for the present study, the displacement of air traffic was done in a more sophisticated way that accounted for aerodynamic constraints as well as for changes in fuel consumption. The procedure for the pro- 
duction of these scenarios is explained in the following section.

\section{Database}

New aircraft inventories with greater vertical resolution and the potential of shifts in flight altitude were prepared and provided within the scope of the TRADEOFF project $^{1}$. Sixteen aircraft-engine-combinations were regarded as representative types for the global fleet (GARDNER, 1998). Fuel-flow profiles for these 16 types were modelled using the PIANO $^{2}$ aircraft performance model, assuming a payload of $70 \%$. Previous aircraft inventories (e.g. SCHMITT and BRUNNER, 1997; GARDNER et al., 1997) specified cruise altitudes rather crudely, being based upon limited data that were applied globally, regardless of aircraft type and mission distance. For the TRADEOFF inventory, considerable effort was put into refining this aspect, given that changes in cruise altitude were a major focus of the work. A separate analysis of real mission data from the EUROCONTROL and FAA air-space domains, using approximately 53000 flights, showed that cruise altitudes correlate with mission distances for the representative aircraft types. Based upon this analysis, cruise altitudes by mission distance were prescribed for each of the representative aircraft types for the calculation of fuel-flow profiles. The fuel-flow profiles were modelled for a number of mission distances for each of the representative aircraft types.

The three-dimensional inventories of fuel consumption, $\mathrm{NO}_{x}$ emissions and distance travelled were calculated using the FAST $^{3}$ model. FAST comprises a movement database and a library of programs, spreadsheets, tables and database queries that assign a corresponding fuel-flow profile to each of the movements from the database. FAST then calculates the inventories of fuel consumption, $\mathrm{NO}_{x}$ emissions and distance travelled on a global $1^{\circ} x 1^{\circ}$ grid on a monthly mean basis.

In 1992, the base year of this study, the vertical distance of flight levels (FL) was $2000 \mathrm{ft}$, e.g. FL290, FL310, FL330 ..., FL410, these flight levels correspond to altitudes of $29000 \mathrm{ft}, 31000 \mathrm{ft}, 33000 \mathrm{ft}, \ldots 41000$ $\mathrm{ft}$, respectively ${ }^{4}$. In order to represent increased and decreased flight altitudes, increments of real flight levels were chosen. Scenarios were developed for $2000 \mathrm{ft}$,

\footnotetext{
${ }^{1}$ TRADEOFF was a project in the European Fifth Framework Programme, (www.iac.ethz.ch/tradeoff/).

${ }^{2}$ PIANO $=$ Project Interactive Analysis and Optimisation. (www.lissys.demon.co.uk/)

$3 \overline{\text { FAST }}=$ Future Civil Aviation Scenario Software Tool (Kingdon R.D., 2000: FAST v1.0 User Manual, Propulsion Department, DERA Pyestock, Farnborough, Hampshire, GU14 0LS, UK).

${ }^{4}$ These flight levels are defined by pressure values. The pressure levels are assigned a height (in ft) according to the US standard atmosphere.
}

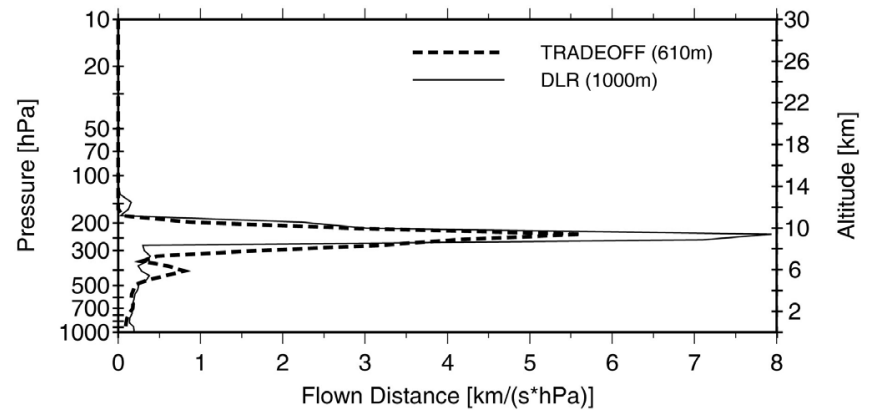

Figure 2: Annual mean flown distances horizontally integrated for each ECHAM4.L39(DLR) model level for the TRADEOFF and DLR base case inventories. The numbers in parentheses denote the original vertical resolutions of the inventories. The right axis provides the mean altitudes of the ECHAM pressure levels.

$4000 \mathrm{ft}, 6000 \mathrm{ft}$ and $8000 \mathrm{ft}$ lower maximum flight altitudes and for $2000 \mathrm{ft}$ maximum higher flight altitudes. The altitude changes were specified by aircraft type and by mission distance. For the altitude increase scenario, however, some aircraft types would not be able to perform the flight. This was the case for some long mission distances with high flight altitudes. Thus, shifts in altitude were made only when feasible, otherwise the flight altitudes for those particular aircraft types and mission distances were retained from the base case scenario. For the downwards displacement by $8000 \mathrm{ft}$ a number of missions could not be performed because of insufficient fuel. As this scenario was incomplete, it was not included in the subsequent analysis. An overview of the scenarios used in the present study is given in Table 1.

Overall comparisons were made with the DLR2 inventory (SCHMITT and BRUNNER, 1997) that has been used in former contrail studies. The DLR2 inventory is based on the same air traffic movement database, as the TRADEOFF inventory, but used a different aircraftengine-performance model for the calculation of the fuel-flow data (SCHMITT and BRUNNER, 1997). However, both inventories are in close agreement with regard to their total numbers of flown distances, fuel consumption and $\mathrm{NO}_{x}$ emissions. The vertical discretisation of the TRADEOFF inventory was chosen to resemble real flight level intervals of $2000 \mathrm{ft}$, whereas the DLR2 inventory used a vertical discretisation of $1 \mathrm{~km}^{5}$. Figure 2 shows the vertical distributions of horizontally integrated flown distances.

The TRADEOFF inventory shows a slightly broader peak than does the DLR inventory, although the maximum is at very similar altitudes. The reason for the different traffic densities by altitude is that the TRADEOFF inventory distributes flights according to an analysis of air-traffic data, whereas the DLR2 inventory was based

\footnotetext{
${ }^{5}$ Also the DLR-2 inventory uses pressure as vertical coordinate and assigns altitudes $(\mathrm{km})$ according the US standard atmosphere.
} 
Table 1: Global annual totals for flown distance and fuel consumption for the DLR2 (SCHMITT and BRUNNER, 1997) and the TRADEOFF inventories for 1992 operations, resultant global mean contrail coverage and corresponding radiative forcing. The notes next to contrail coverage indicate whether the measure used for contrail parameterisation was either flown distance or fuel consumption. Values in parentheses behind RF values represent our best estimate for contrail radiative forcing (for explanation see text and for details see MARQUART and MAYER, 2002).

\begin{tabular}{|l|l|l|l|l|}
\hline Inventory & $\begin{array}{l}\text { Flown } \\
\text { Distance } \\
{\left[{ }^{*} \mathbf{1 0} \mathbf{k m} / \mathbf{y r}\right]}\end{array}$ & $\begin{array}{l}\text { Fuel } \\
\text { Consumption } \\
{[\mathbf{T g} / \mathbf{y r}]}\end{array}$ & $\begin{array}{l}\text { Global Mean } \\
\text { Contrail } \\
\text { Coverage [\%] }\end{array}$ & $\begin{array}{l}\text { Net RF by } \\
\text { Contrails } \\
{\left[\mathbf{m W} / \mathbf{m}^{2}\right]}\end{array}$ \\
\hline DLR2 & 18.0 & 112.2 & $\begin{array}{l}0.052 \text { (distance) } \\
0.057 \text { (fuel) }\end{array}$ & $\begin{array}{l}2.1(3.2) \\
2.3(3.5)\end{array}$ \\
\hline $\begin{array}{l}\text { TRADEOFF } \\
\text { base case }\end{array}$ & 17.1 & 111.5 & $\begin{array}{l}0.047 \text { (distance) } \\
0.052 \text { (fuel) }\end{array}$ & $\begin{array}{l}1.9(2.9) \\
2.0(3.1)\end{array}$ \\
\hline $\begin{array}{l}\text { TRADEOFF } \\
+2 \mathrm{kft}\end{array}$ & 17.1 & 111.0 & 0.050 (distance) & $2.0(3.1)$ \\
\hline $\begin{array}{l}\text { TRADEOFF } \\
-2 \mathrm{kft}\end{array}$ & 17.1 & 114.5 & 0.041 (distance) & $1.6(2.5)$ \\
\hline $\begin{array}{l}\text { TRADEOFF } \\
-4 \mathrm{kft}\end{array}$ & 17.1 & 115.5 & 0.034 (distance) & $1.3(2.0)$ \\
\hline $\begin{array}{l}\text { TRADEOFF } \\
-6 \mathrm{kft}\end{array}$ & 17.1 & 118.0 & 0.026 (distance) & $1.0(1.6)$ \\
\hline
\end{tabular}

upon more idealized assumptions. Given that the formation of contrails is sensitively dependent on altitude (Figure 1), a close representation of the vertical distribution of flight altitudes is essential to estimate the respective climate impact.

\section{Method}

For the present study a parameterisation for line-shaped contrails (PONATER et al., 2002) was applied, which was developed for the ECHAM4.L39 (DLR) model (ROECKNER et al., 1996, LAND et al., 1999, 2002). It is based on the thermodynamic theory of contrail formation (Schmidt-Appleman theory) and takes into account that contrails only persist if the ambient air is supersaturated with respect to ice. The contrail parameterisation was formulated in a way that is consistent with the ECHAM's cloud parameterisation scheme. Within the contrail parameterisation, the potential contrail coverage is calculated by means of a critical humidity value, which itself is dependent on the ambient temperature, the emission index of water vapour and the overall propulsion efficiency $\eta$ of the aircraft. For the propulsion efficiency, an average value of $\eta=0.3$ was assumed (SCHUMANN, 1996). However, the sensitivity of the calculations to realistic variations in $\eta$ is small (SAUSEN et al., 1998). In contrast to the study of PONATER et al. (2002), the distance travelled was used as a weighting factor to calculate the contrail coverage from the potential contrail coverage, rather than the fuel used. The air traffic density is a more physically based measure for the calculation of contrail coverage than the fuel consumption within a grid box. Also the calibration procedure was upgraded over that used in earlier studies. SAUSEN et al. (1998) and PoNATER et al. (2002) calibrated the mean contrail coverage over the west Europe - east Atlantic region to satellite observations of BAKAN et al. (1994) and a daytime mean coverage of $0.5 \%$. In the present study, the approach of MARQUART et al. (2003) was adopted and the contrail coverage for the same region was calibrated to a 24-hour mean of $0.375 \%$. For the calibration procedure only those contrails were included whose optical depth exceeded a threshold value of 0.02 (PONATER et al., 2002). Within the contrail parameterisation scheme, sufficient ice water needs to be available within the grid box, which enables the contrails to persist during a whole model time step (i.e. 30 minutes); otherwise the contrails will evaporate and not be included. For total contrail coverage all model layers that contain a fractional coverage of contrails were summed up using a random overlap assumption (SAUSEN et al., 1998). Five or three year integrations of constant 1992 conditions were run after the model reached equilibrium conditions. The monthly or annual means of the integration period were then analysed.

In this study, we measure climate change from contrails by radiative forcing, which is considered as one of the most appropriate climate change metrics for aviation impacts (PRATHER et al., 1999). Radiative forcing (e.g. SHINE et al., 1990; HANSEN et al., 1997) is defined as the change of the net radiative flux at some level in the atmosphere that instantaneously results from a perturbation, e.g. a change in radiatively active species or clouds. In the present study radiative forcing of contrails was calculated online in the GCM using the stratosphereadjusted radiative forcing at the tropopause (STUBER et al., 2001). With regard to the calculation of the contrail radiative forcing, all contrails were included, also those with optical depth values below the visibility criterion. In Table 1 only the annual mean values for net radiative 


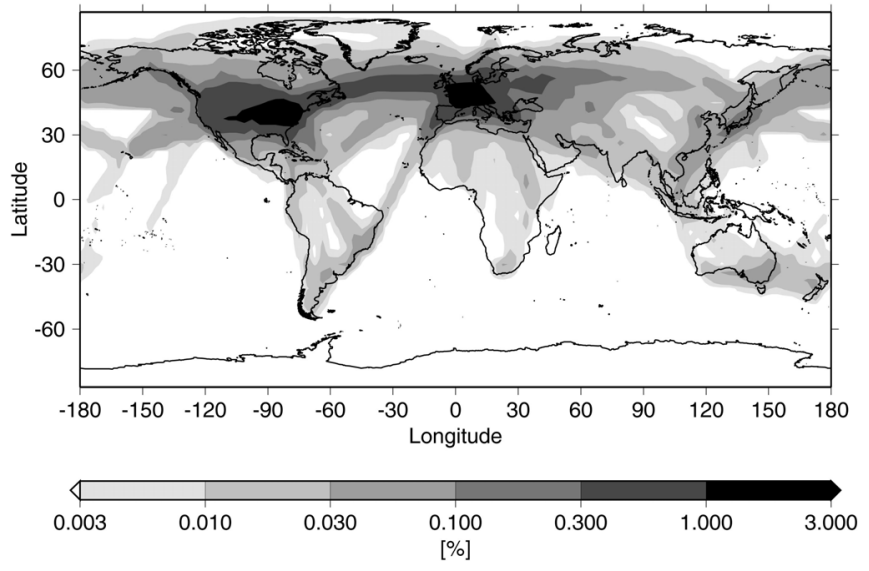

Figure 3: Visible contrail coverage calculated by the ECHAM GCM using the TRADEOFF inventory of flown distances for the year 1992.

forcing are presented, which comprise the sum of the long- and shortwave components. According to MARQUART and MAYER (2002), the global mean longwave forcing from contrails is systematically underestimated within the ECHAM radiative transfer scheme because of the exclusion of longwave scattering. Therefore, contrail radiative forcing values are corrected by a $25 \%$ offset to the longwave radiative forcing. These corrected values are considered as best estimates for contrail radiative forcing and are also given in Table 1.

\section{Contrail coverage}

\subsection{Analysis of the TRADEOFF 1992 base case - comparison with former results from the ECHAM GCM}

The annual mean global contrail coverage determined with the ECHAM GCM using the TRADEOFF inventory about flown distances for the year 1992 is shown in Figure 3. In the following, this inventory and the respective simulation are referred to as the 'base case'. The global mean coverage of linear contrails for this base case was calculated to be $0.047 \%$. MARQUART et al. (2003) found the annual mean global contrail coverage to be $0.06 \%$ for 1992 .

This difference arises from using two different air traffic inventories and from using fuel consumption rather than flown distances as a measure for the air traffic density to calculate the contrail coverage. The differences arising from using flown distances rather than fuel consumption were investigated by considering the ratio of flown distances to fuel consumption, for the TRADEOFF 1992 inventories for altitudes above $5 \mathrm{~km}$ (Figure 4, upper panel). The global mean ratio of flown distances to fuel consumption above $5 \mathrm{~km}$ altitude is approximately $0.18 \mathrm{~km} / \mathrm{kg}$. Regions such as Europe and the United States, where this ratio is higher than the mean value

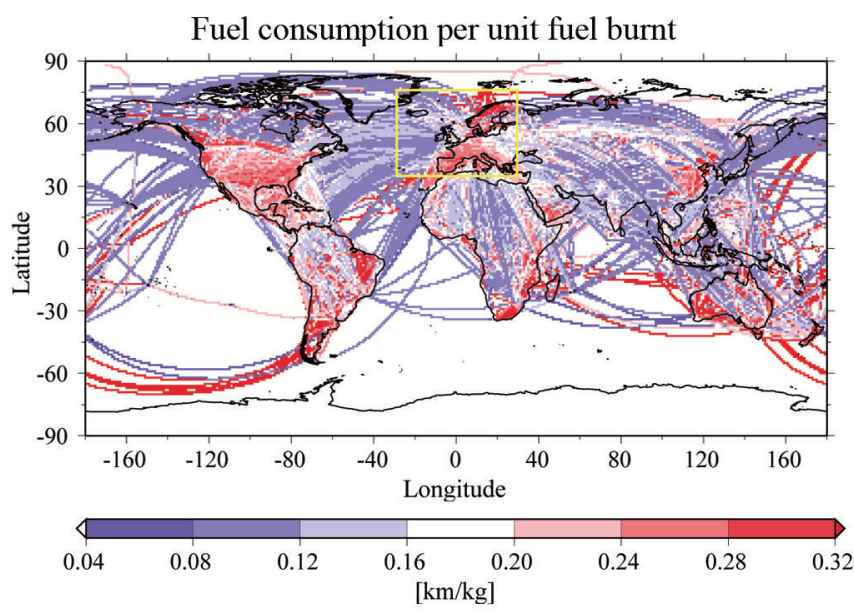

Ratio of contrails from flown distance to those from fuel burnt

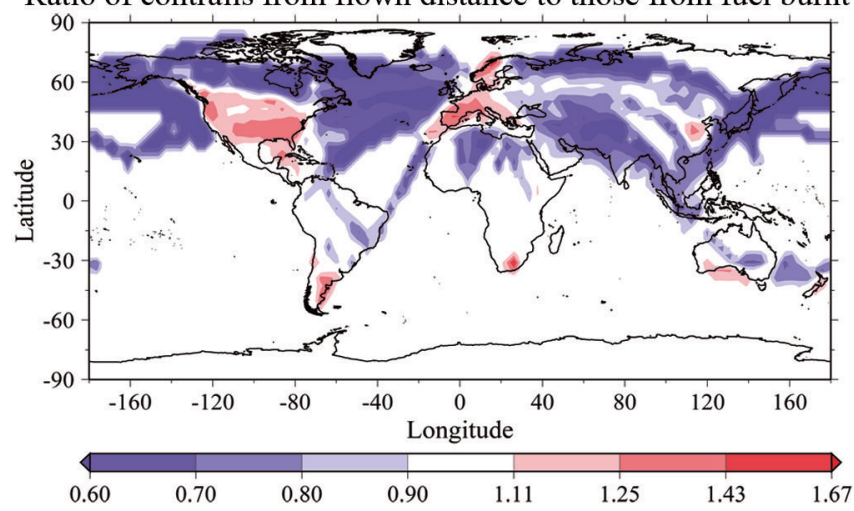

Figure 4: Upper panel: Annual mean ratio of flown distance to fuel consumption for each grid box of the inventory above $5 \mathrm{~km}$ altitude, the yellow box indicates the calibration area. Lower panel: Ratio of contrail coverage calculated by using flown distance to that calculated by using fuel consumption.

are marked with red colours in Figure 4 (upper panel). This higher mean value arises from the predominance of short-haul flights over these regions performed with smaller aircraft which generally consume less fuel per flight $\mathrm{km}$ than larger-capacity aircraft (e.g. GARDNER, 1998). In contrast to this, the bluish areas are characterized as regions dominated by long-range intercontinental flights with large and wide bodied aircraft which consume comparatively more fuel per flight $\mathrm{km}$.

Because of these systematic differences, the geographical distribution of contrail coverage is affected accordingly (Figure 4, lower panel): if flown distances instead of fuel consumption are used as a measure of air traffic, contrail coverage increases in regions with predominantly short-haul air traffic (e.g., Europe, USA, reddish colours in Figure 4, lower panel), while contrail coverage is reduced in regions with prevailing long distance flights (e.g. North Atlantic Flight Corridor, bluish colours in Figure 4, lower panel). In total this results in a relative decrease of global contrail coverage by almost $10 \%$ (Table 1). 

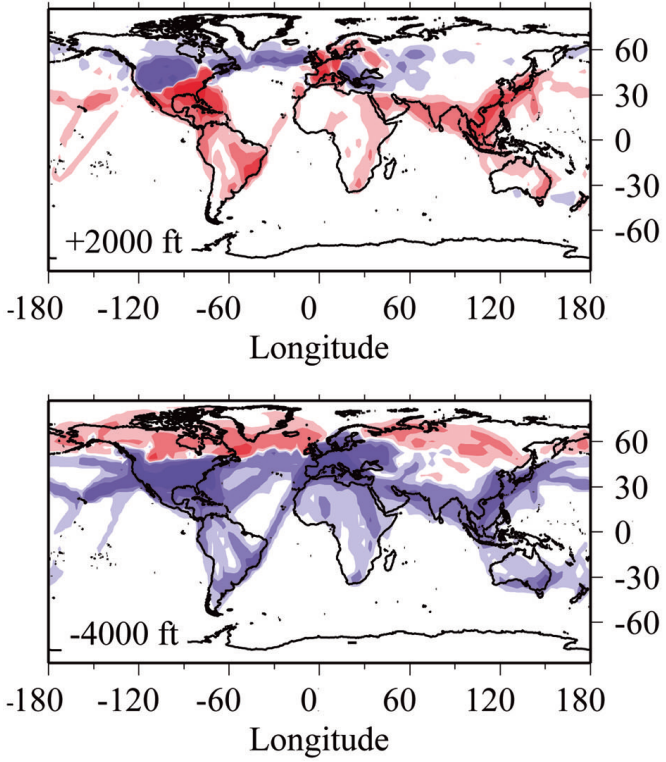

\begin{tabular}{|llllllllllll}
\hline & & & & & & & & & \\
-0.300 & -0.100 & -0.030 & -0.010 & -0.003 & 0.003 & 0.010 & 0.030 & 0.100 & 0.300 \\
\hline$\%]$
\end{tabular}

Figure 5: Changes of annual mean contrail coverage from displaced flight altitudes by $2000 \mathrm{ft}$ up (upper left), $2000 \mathrm{ft}$ down (upper right), $4000 \mathrm{ft}$ down (lower left), and $6000 \mathrm{ft}$ down (lower right) relative to the base case [\% of the total area].

\subsection{Impact of flight altitude}

Within the TRADEOFF project scenarios with displacements of the maximum flight altitude by $-2000 \mathrm{ft}$, $-4000 \mathrm{ft},-6000 \mathrm{ft}$ and $+2000 \mathrm{ft}$ were created. An overview of these scenarios is given in Table 1, which reveals that a penalty in fuel consumption results for lower cruise altitudes because of suboptimal aerodynamics of the airframe and engine combination. Global annual mean values of contrail coverage for each of the investigated scenarios are also given in Table 1. Compared with the base case with standard flight altitudes, a decrease in global contrail coverage resulted for all lower flight altitudes, reaching a maximum decrease of almost $45 \%$ for the most extreme scenario of $-6000 \mathrm{ft}$, whereas flying at higher altitudes $(+2000 \mathrm{ft})$ resulted in a relative increase of global annual mean contrail coverage by about $6 \%$. These global mean values result from integrals over regionally very different, sometimes even opposite changes in contrail cover. The geographic distributions of absolute changes in contrail coverage for each scenario are shown in Figure 5.

For the three scenarios with lower cruise altitudes, the general pattern of changes in contrail coverage shows some characteristic features: an increase in contrail coverage in the northern extra-tropics and a decrease in the tropics (relative to the base case scenario). In tropical regions cruise altitudes are usually located well below the tropopause (Figure 1). If air traffic is displaced downwards, temperature and humidity con- ditions are no longer suitable for the formation of persistent contrails. Tropical contrail coverage is thus reduced with a downwards displacement of cruise altitudes. For the $-6000 \mathrm{ft}$ case nearly no contrails will form equatorwards of $30^{\circ} \mathrm{N}$. In mid-latitudes it is useful to distinguish between intercontinental/long-haul flight regions (e.g. the North Atlantic Flight Corridor) that are dominated by higher cruising altitudes, and domestic or intra-continental flight regions which have a widespread vertical distribution of air traffic including both high and low cruise altitudes. The vertical distribution for domestic/intra-continental flights arises from both air traffic management constraints and the different mix of aircraft types used. For flights over the North American and the European continents, contrail coverage is reduced with decreasing flight altitudes as the main part of the air traffic, which already occurs at relatively low altitudes, is displaced into even lower tropospheric regions where threshold conditions of temperature and humidity are less likely to be exceeded. Contrary to this, the long distance air traffic in the northern mid-latitudes occurs to some extent in the cold and dry lowermost stratosphere in the base case. A small decrease in flight altitudes by $2000 \mathrm{ft}$ would therefore shift these longdistance flights from the lowermost stratosphere into the upper troposphere where ambient conditions are most suitable for the formation of persistent contrails. For a further downward displacement by $4000 \mathrm{ft}$ or $6000 \mathrm{ft}$, the high altitude air traffic southwards of about 45 to $50^{\circ} \mathrm{N}$ is shifted further down into tropospheric regions 
with ambient conditions that are no longer suitable for the formation of persistent contrails (Figure 5).

Displacing air traffic upwards revealed a qualitatively inverted pattern from the equivalent downward displacement (Figure 5). Flying $2000 \mathrm{ft}$ higher leads to an increase in contrail coverage over the tropics and those parts of northern mid-latitudes where air traffic at lower flight altitudes is prevalent. By displacing cruise altitudes upwards by $2000 \mathrm{ft}$, air traffic enters colder levels of the upper troposphere where persistent contrails are more likely to form. In contrast to this, a decrease in contrail coverage occurs in northern mid-latitudes where high altitude flights prevail. Over these regions, the displacement of air traffic upwards by $2000 \mathrm{ft}$ has the consequence that a sufficiently large part of air traffic enters the stratosphere, where threshold conditions for thermodynamic contrail formation and persistence can rarely be fulfilled.

In general, the results of cruise altitude changes on contrail coverage can be summarized as follows: a downward displacement of air traffic resulted in a decrease of contrail coverage in the tropics, subtropics and the low-level air traffic in mid-latitudes, and an increase of contrail coverage in regions with prevailing high altitude air traffic in the mid-latitudes. For an upward displacement of air traffic the opposite was true, contrail coverage increased in the tropics, subtropics, and regions with predominantly low-level flights, while it decreased in regions in which long distance air traffic at high altitudes prevails.

\subsection{Impact of seasonal cycle}

From previous studies, it is known that contrail coverage is subject to a pronounced seasonal cycle from its dependency on ambient meteorological conditions (e.g. SAUSEN et al., 1998; MINNIS et al., 1999; PONATER et al., 2002). The factors that affect the seasonal changes in contrail coverage are variations in the flight movement data and varying meteorological conditions. The inventories of flown distances show a small seasonal cycle, which on a global scale, deviates from the monthly to the annual mean by less than $3 \%$. By contrast, monthly values of global contrail coverage deviate from the annual mean by up to $40 \%$. Hence the main reason for the seasonal variation of the contrail coverage is the variability of the meteorological conditions rather than the variability of aircraft movements.

Figure 6 shows monthly mean January and July values of changes in contrail coverage from a downward displacement of air traffic by $6000 \mathrm{ft}$. This figure reveals considerable differences in the effects a displacement in flight altitudes may have in different seasons. For January, the pattern is similar to the annual mean; i.e. reductions in contrail coverage in the tropics and subtropics, but an increase in regions with prevailing high-altitude

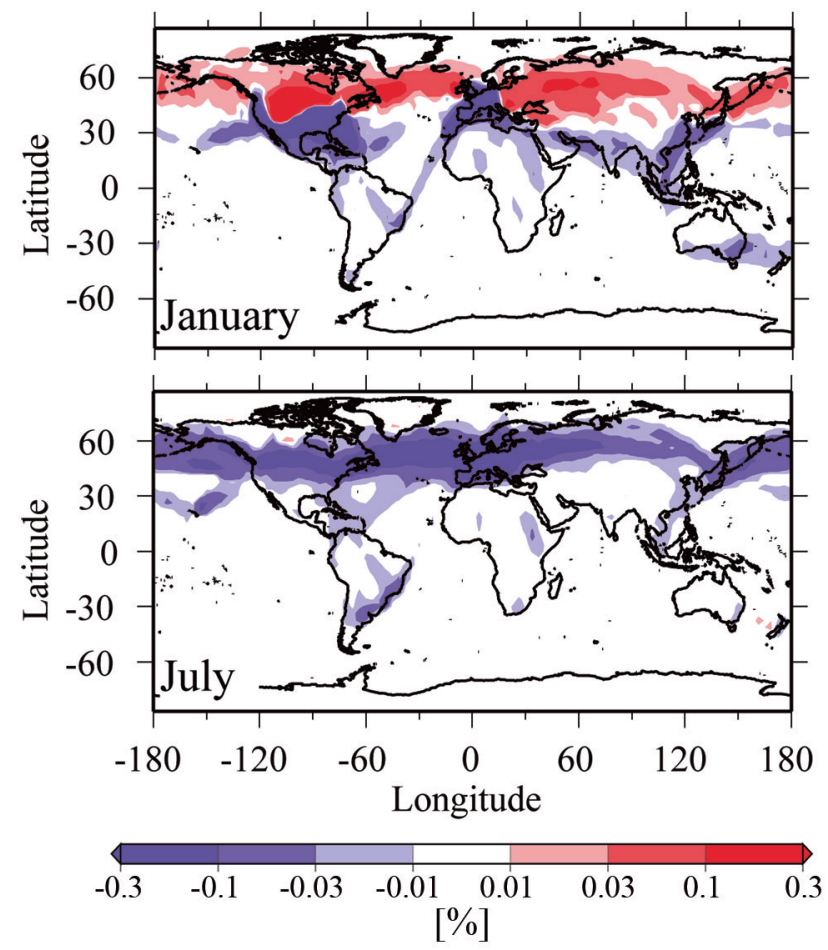

Figure 6: Absolute changes in contrail coverage due to a downward displacement of air traffic by $6000 \mathrm{ft}$ for January (upper panel) and July mean values (lower panel).

air traffic at northern mid latitudes. Contrary to this, contrail coverage decreases in nearly all regions in July. This is attributable to higher tropospheric temperatures in the northern hemisphere summer, restricting the formation of persistent contrails (Figure 1, lower panel). A similar but less pronounced pattern is also found for a smaller downward shift of air traffic by 2000 or $4000 \mathrm{ft}$ (not shown).

In the $+2000 \mathrm{ft}$ scenario (not shown) in January, an increase of contrail coverage is only found in the tropics and over Central Europe, whereas at northern midlatitudes contrail coverage is reduced similarly to the annual mean (Figure 5, upper left). In July, an upward displacement of air traffic results in an overall increase in contrail coverage except for very small regions over the northern mid-latitudes. This increase is mainly caused by a higher tropopause in northern mid-latitudes in July.

\section{Radiative forcing}

Radiative forcing from contrails does not only depend upon total contrail coverage and its regional distribution but also on the optical properties of the contrails. PONATER et al. (2002) found the optical properties of contrails to be dependent on altitude, latitude and season. The optical depth of contrails resulted to be higher for lower flight altitudes, for lower latitudes and for warmer seasons. In general, optically thicker 

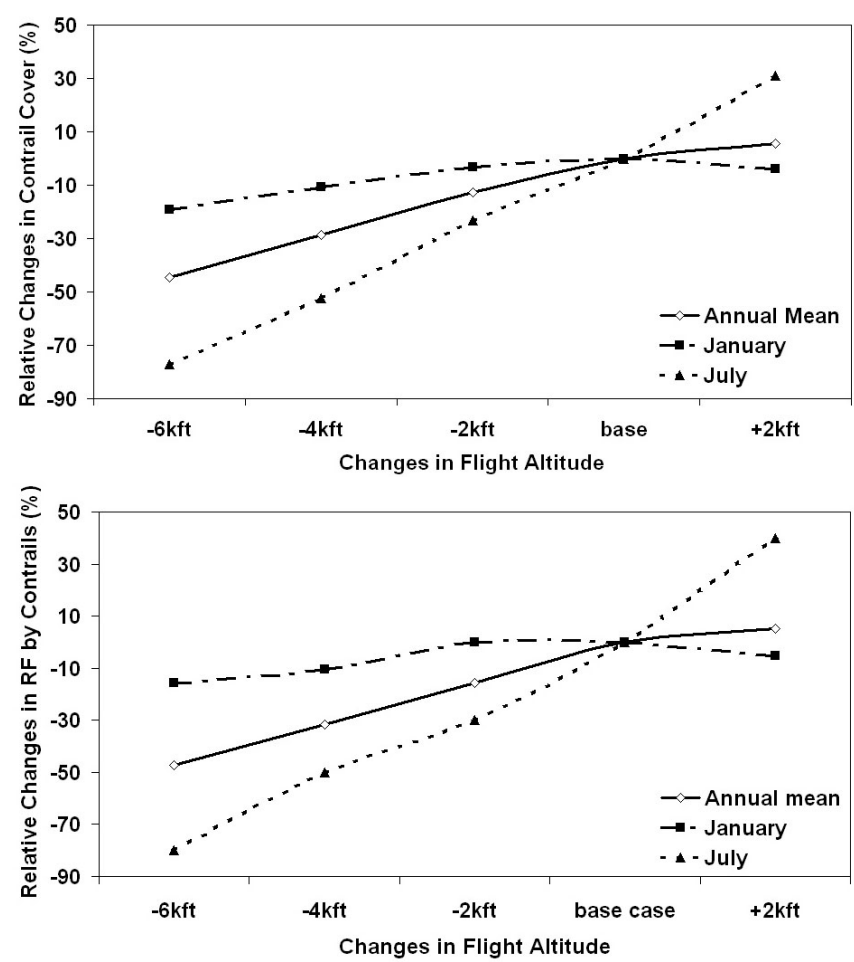

Figure 7: Relative changes in global mean contrail coverage (upper panel) and radiative forcing by contrails (lower panel) as functions of changes in mean cruise altitude. The results for the annual mean and for January and July are displayed.

contrails are expected to be radiatively more important (MEERKÖTTER et al., 1999).

Figure 7 shows the relative changes in global contrail coverage (upper panel) and radiative forcing (lower panel) as a function of changes in flight altitudes. Percentage changes are given relative to the base case for the annual mean and for January and July mean values for all scenarios. Both diagrams show very similar characteristics. The maximum reduction of radiative forcing by contrails is found for the $-6000 \mathrm{ft}$ scenario. The global annual mean radiative forcing is reduced by almost $45 \%$ compared with the base case, which is similar to the relative changes of contrail coverage. The seasonal variation for radiative forcing with associated altitude changes resembles the seasonal variation of contrail coverage. Annual mean values for radiative forcing for all scenarios are given in Table 1 . The variation of optical properties associated with changes in flight altitude is very small compared with the changes in contrail coverage. Therefore, seasonal variations in contrail radiative forcing are dominated by the large variations in contrail coverage arising from changes in cruise altitudes rather than by variations in optical depth.

\section{Caveat}

We note that the ECHAM4.L39(DLR) model, like most other presently existing GCMs, suffers from a distinct temperature error in the extratropical tropopause region - the so-called 'cold bias ${ }^{6}$. The difference between observed and modelled temperatures reaches about 10 $\mathrm{K}$ for the annual mean at an altitude of $200 \mathrm{hPa}$ (ROECKNER et al., 1996, MARQUART et al., 2003) but is restricted to regions polewards from $40^{\circ} \mathrm{N}$ and $40^{\circ} \mathrm{S}$. This bias impacts the parameterisation of contrail coverage in so far as the calibration area is also affected by the temperature bias, which leads to an artificial reduction of tropical contrail coverage (PONATER et al., 2002, MARQUART et al., 2003). In order to investigate to which extent the results and conclusions of the present study are affected by the 'cold bias', sensitivity experiments for $6000 \mathrm{ft}$ lower and for $2000 \mathrm{ft}$ higher flight altitudes were performed with an experimental model version of the ECHAM GCM in which the temperature bias was reduced to half of the amount compared with the standard model version (PONATER et al., 2003). For the purpose of comparison the same factor for the calibration of contrail coverage was used for the reduced cold bias model as for the standard model.

Naturally, the absolute values of global contrail coverage are slightly different for the reduced cold bias model compared with the standard model, as the different values for temperature and humidity affect the distribution of potential contrail coverage. However, the main purpose for this sensitivity test is to check, if relative changes of contrail coverage and net radiative forcing for different flight altitudes (relative to the corresponding base case with standard flight altitudes) are substantially different for the model version with reduced cold bias.

For a downwards displacement of air traffic by 6000 $\mathrm{ft}$, both the relative changes in global contrail coverage and radiative forcing are very similar: The respective values from the reduced cold bias model deviate from those from the standard model by less than $10 \%$. For the $2000 \mathrm{ft}$ higher flight altitudes however, results are not as resembling. Although the sign of relative changes in contrail coverage and radiative forcing associated with the altitude change remains the same, the results of the reduced cold bias model deviate by around $30 \%$ for contrail coverage and roughly $50 \%$ for radiative forcing from the results from the standard model. This larger deviation for the higher flight altitude scenario is not unexpected, as meteorological conditions (temperature and humidity) change most in altitudes above $250 \mathrm{hPa}$ in the reduced cold bias model, which naturally affects higher flight altitudes more intensively. This larger deviation of global contrail coverage and radiative forcing values for higher flight altitudes may be ascribed to a variety of reasons, such as differing optical properties, a different

\footnotetext{
${ }^{6}$ The German research project (COBI) investigates potential reasons for the 'cold bias' and develops possible solution strategies (see www.pa.op.dlr.de/cobi).
} 
tropopause height and a modified geographical distribution of potential contrail coverage. A more detailed analysis is required to investigate the effect of a reduced cold bias on all these effects. This will be done with a more sophisticated and physically consistent model version with reduced cold bias, which will be available in the near future.

\section{Conclusions and outlook}

The effects of changes in cruise altitudes on contrail formation and contrail radiative forcing were investigated by means of the ECHAM GCM and its contrail parameterisation scheme. For this purpose, a series of air traffic scenarios with increased $(+2000 \mathrm{ft})$ or decreased $(-2000$ $\mathrm{ft},-4000 \mathrm{ft},-6000 \mathrm{ft}$ ) flight altitudes was used. For all scenarios assuming decreased flight altitudes a reduction of contrail coverage is found. The strongest reduction of global annual mean contrail coverage was achieved by displacing air traffic down by $6000 \mathrm{ft}$ and yielded a 45 $\%$ decrease of global contrail coverage in comparison with a base case scenario with standard cruise altitudes. In contrast to this, an upward displacement of air traffic by $2000 \mathrm{ft}$ resulted in a $6 \%$ increase of global annual mean contrail coverage over the base case. Changes in contrail radiative forcing that are associated with altitude changes were found to be very similar to those of contrail coverage. For both contrail coverage and contrail radiative forcing, strong seasonal sensitivity and considerable regional differences were found for all investigated air traffic scenarios.

This study shows a potential for reducing contrail coverage and radiative forcing from contrails by changing aircraft cruise altitudes. The way this has been done is rather simplistic as flight altitudes were changed uniformly in space an time. Particularly, considering the strong seasonal and geographical differences that were found, a more sophisticated approach is certainly desirable. An adaptation to latitudinal, seasonal, and ideally to short-term changes in ambient parameters would potentially avoid contrail formation more effectively than a global increase or decrease of flight altitudes.

Contrail radiative forcing is only one of several factors which play a major role in aviation's climate impact. The effects of changes in flight altitude on the concentration and distribution of other aircraft emissions, such as $\mathrm{NO}_{x}$ (and its impact on $\mathrm{O}_{3}$ and $\mathrm{CH}_{4}$ ) and $\mathrm{CO}_{2}$ were also investigated within the TRADEOFF project (SAUSEN and SCHUMANN, 2000; GREWE et al., 2002; GAUSS et al., 2004). In general, fuel burn and hence $\mathrm{CO}_{2}$ emissions will increase for decreasing flight altitudes but will decrease for a small increase in flight altitudes, assuming that current aircraft are used, as for the present study (see Table 1). For lower flight altitudes aircraft $\mathrm{NO}_{x}$ emissions increased, but net $\mathrm{O}_{3}$ and $\mathrm{CH}_{4}$ concentrations decreased compared with the base case scenario (GREWE et al., 2002).

For the development of strategies considering the mitigation of the overall climate impact of aircraft emissions all these different effects need to be quantified with respect to their radiative forcing and the corresponding atmospheric temperature response. Regarding the latter, the atmospheric residence time of the different radiatively active agents must be considered, which is, for example some hours for contrails but about a century for $\mathrm{CO}_{2}$. This study has only explored the contrail radiative forcing response from changed cruise altitudes, and not the overall radiative forcing response from all aircraft-induced contributions. Determining the latter requires further numerical simulations that were beyond the scope of the present study. Finding the environmentally and economically optimal flight altitudes still remains a challenge. Much more refined analyses are required before recommendations could be made regarding the implementation of altitude changes in air traffic regimes.

\section{Acknowledgements}

The authors are grateful to Prof. Michael PONATER for helpful discussions and the data from the cold bias sensitivity runs. This study forms a contribution to the European Fifth Framework Project, TRADEOFF (EVK2CT-1999-0030) and funding from the European Commission is gratefully acknowledged. DSL was also supported by the UK Department for Transport and the Department for Trade and Industry.

\section{References}

BAKan S., M. Betancor, V. GAYler, H. Grassl, 1994: Contrail frequency over Europe from NOAA-satellite images. - Ann. Geophys. 12, 962-968.

GARDNER, R.M. (Ed.), 1998: ANCAT/EC2 aircraft emissions inventories for 1991/92 and 2015: Final Report. EUR18179, ANCAT/EC Working Group, 84 pp., appendices. ISBN-92-828-2914-6.

Gardner R. M., K. AdAms, T. CoOK, S. Ernedal, R. FAlK, E. Fleuti, E. Herms, C.E. Johnson, M. LeCht, D.S. LeE, M. LeECH, D. Lister, B. Massé, M. Metcalfe, P. Newton, A. Schmitt, C. VANDENBERGH, R. VAN DRIMMELEN, 1997: The AN$\mathrm{CAT} / \mathrm{EC}$ global inventory of $\mathrm{NO}_{x}$ emissions from aircraft. -Atmospheric Environment 31, 1751-1766.

GAuss M, I. IsAKSEN, V. Grewe, M. Koehler, D. Hauglustaine, D.S. LEE, 2004: Impact of Aircraft $\mathrm{NO}_{x}$ Emissions: Effects of Changing the Flight Altitude. - In: Aviation, Atmosphere and Climate (AAC), Proceedings of a European Conference, Friedrichshafen, Germany, 30 June to 3 July 2003, ISBN 92-894-54342. [Available from Georgios.Amanatidis@cec.eu.int or www.pa.op.dlr.de/aac]. 
Grewe, V., M. DAmeris, C. Fichter, D.S. Lee, 2002: Impact of aircraft $\mathrm{NO}_{x}$ emissions. Part 2: Effects of lowering the flight altitude. - Meteorol. Z. 11, 197-205.

HANSEN, J., M. SATO, R. RUEDY, 1997: Radiative forcing and climate response, - J. Geophys. Res. 102, (D6), 68316864.

LAnd, C., M. Ponater, R. SAusen, E. RoeckNER, 1999: The ECHAM4.L39(DLR) Atmosphere GCM. Technical Description and Model Climatology. - DLRForschungsbericht 1999-31, ISSN 1434-8454, 45 pp. [Available from Deutsches Zentrum für Luft- und Raumfahrt e.v., Porz-Wahnheide, Linder Höhe, 51147 Köln, Germany].

LAND, C., J. Feichter, R. SAUSEN, 2002: Impact of vertical resolution on the transport of passive tracers in the ECHAM4 model. Tellus (B) 54, 344-360.

MANNSTEIN, H., U. SCHUMANN, 2005: Aircraft induced contrail cirrus over Europe. Meteorol. Z. 14, 549-554.

MARQUART, S., B. MAYER, 2002: Towards a reliable GCM estimation of contrail radiative forcing. Geophys. Res. Lett. 29(8), 1179, DOI 10.1029/2001GL014075.

MARquart, S., M. Ponater, F. Mager, R. SAusen, 2003: Future development of contrail cover, optical depth and radiative forcing: Impacts of increasing air traffic and climate change. - J. Climate 16, 2890-2904.

MeERKötter, R., U. Schumann, D.R. Doelling, P. Minnis, T. NAKAJima, Y. TSUShima, 1999: Radiative forcing by contrails. - Ann. Geophys. 17, 1080-1094.

Meyer R., H. Mannstein, R. MeErkötter, U. SCHUMANN, P. WENDLING, 2002: Regional radiative forcing by line-shaped contrails derived from satellite data, - J. Geophys. Res. 107, (D10), 4104, DOI10.1029/2001JD000426.

Minnis, P., U. SCHUMANn, D.R. Doelling, K. GiERENS, D.W. FAHEY, 1999: Global distribution of contrail radiative forcing. - Geophys. Res. Lett. 26, 18531856.

Minnis, P., J.K. Ayers, R. Palikonda, D. Phan, 2004: Contrails, cirrus trends, and climate. - J. Climate 17, 16711685.

MYHRE G., F. STORDAL, 2001: On the tradeoff of the solar and thermal infrared radiative impact of contrails. - Geophys. Res. Lett. 28, 3119-3122.

PenNer, J., D.H. Lister, D.J. GRiggs, D.J. DokKen, M.MCFARLAND (Eds), 1999: Aviation and the global atmosphere. A special report of IPCC working groups I and II. Intergovernmental Panel on Climate Change. - Cambridge University Press, Cambridge, United Kingdom.

Ponater, M., S. Marquart, R. SAusen, 2002: Contrails in a comprehensive global climate model: Parameterisation and radiative forcing results. - J. Geophys. Res. 107 (D13), 4164, DOI: 10.1029/2001JD000429.

PONATER, M., M. MECH, R. MEERKÖtTER, G. SchWARTz, R. SAuSEN, U. BurkhardT, J. EGGer, C. Fichter, G. Gesell, B. Hildenbrand, C.W. KÖNIG, 2003: COBI: The cold bias in atmospheric general circulation models. Proceedings of the DEKLIM research programme status seminar "Research for the Environment", Bad Münstereifel, October 2003, 437443. [Available from annette.muenzenberg@dlr.de or www.deklim.de].
Prather, M., R. Sausen, A.S. Grossman, J.M. HayWoOd, D. Rind, B.H. SubBarayA, 1999: Potential climate change from aviation. - In: J.E. PENNER, D.H. Lister, D.J. Griggs, D.J. DokKen, M. MCFARland (Eds.): Aviation and the Global Atmosphere. A Special Report of IPCC Working Groups I and III. Cambridge University Press, Cambridge, UK, 185-215.

Roeckner, E., K. Arpe, L. Bengtsson, M. Christoph, M. Claussen, L. Dümenil, M. Esch, M. Giorgetta, U. Schlese, U. SchulzweidA, 1996: The atmospheric general circulation model ECHAM4: Model description and simulation of present-day climate. - Max Planck Institute for Meteorology, Report 218, 90 pp. [Available from Max-Planck-Institut für Meteorologie, Bundesstraße 53, 20146 Hamburg, Germany].

SAUSEN, R., U. SCHUMANN, 2000: Estimates of the climate response to aircraft $\mathrm{CO}_{2}$ and $\mathrm{NO}_{x}$ emissions scenarios. Climatic Change 44, 27-58.

SAUSEN, R., D. NODORP, C. LAND, F. DEIDEWIG, 1996: Ermittlung optimaler Flughöhen und Flugrouten unter dem Aspekt minimaler Klimawirksamkeit. - DLRForschungsbericht 96-13, ISSN 0939-2963, 105 pp. [Available from Deutsches Zentrum für Luft- und Raumfahrt e.v., Porz-Wahnheide, Linder Höhe, 51147 Köln, Germany].

Sausen, R., K. Gierens, M. Ponater, U. Schumann, 1998: A diagnostic study of the global distribution of contrails. Part I: Present day climate. - Theor. Appl. Climatol. 61, 127-141.

SAusen R., V. Grewe, I. ISAKSEn, D. Hauglustaine, D.S. LeE, M. Köhler, U. Schumann, F. Stordal, C. ZEREFOS, 2005: Aviation radiative forcing in 2000: An update on IPCC (1999). - Meteorol. Z. 14, 555-561.

Schmitt, A., B. Brunner, 1997: Emissions from aviation and their development over time. - In: U. SCHUMANN et al. (Eds.): Pollutants from Air Traffic - Results of Atmospheric Research 1992-1997, DLR-Mitteilungen 97-04, ISSN 1434-8462, 301 pp. [Available from Deutsches Zentrum für Luft- und Raumfahrt e.v., Porz-Wahnheide, Linder Höhe, 51147 Köln, Germany].

SCHUMANN, U., 1996: On conditions for contrail formation from aircraft exhausts. - Meteorol. Z. N.F. 5, 4-23.

Shine, K.P., R.G. Derwent, D.J. Wuebbles, J.-J. MorCRETTE, 1990: Radiative forcing of climate. - In Houghton, J.T., G.J. Jenkins, J.J. Epharums (Eds.): Climate Change: The IPCC Scientific Assessment. Cambridge University Press, Cambridge, United Kingdom.

Stordal, F., G. Myhre, D.W. Arlander, T. Svendby, E.J.G. Stordal, W.B. Rossow, D.S. LEE, 2005: Is there a trend in cirrus cloud cover due to aircraft traffic? - Atmos. Chem. Phys. Discuss. 4, 6473-6501.

Stuber, N., R. SAusen, M. Ponater, 2001: Statosphere adjusted radiative forcing calculations in a comprehensive climate model. - Theor. Appl. Climatol. 68, 125-135.

Zerefos, C.S., K. Eleftheratos, D.S. Balis, P. ZANIS, G. TSElioudis, C. Meleti, 2003: Evidence of impact of aviation on cirrus cloud formation. - Atmos. Chem. Phys. Discuss. 3, 3335-3359. 